\title{
Electronic Load Controller based on Dimmer Circuit and Stepper Motor for 5 kW Micro-Hydro Power Plant
}

\author{
Abdul Hafid ${ }^{1, *}$, Andi Faharuddin ${ }^{1}$ and Abdul Rajab ${ }^{2}$ \\ ${ }^{I}$ Faculty of Engineering, Muhammadiyah University of Makassar, Indonesia \\ ${ }^{2}$ Faculty of Engineering, Andalas University, Padang, Indonesia
}

('Corresponding author's e-mail: abdul.hafid@unismuh.ac.id)

Received: 29 August 2020, Revised: 8 May 2021, Accepted: 29 May 2021

\begin{abstract}
This paper presents the results of research on a new schematic generator load controller simulation, namely an electronic load controller based on a dimmer circuit and a stepper motor for a small-scale 5 $\mathrm{kW}$ micro-hydro. The load controller is built from a dimmer circuit and a stepper motor with program control using Matlab software, and the PPI 8255 interface device. Using a dimmer circuit built from diac, triac, a variable resistor (pot), and capacitor components. As well as using a 28BYJ-48 stepper motor. Simulation is made to determine the performance of the load controller in controlling the distribution of power to the ballast load when the generator supplies power to consumers less than the full load of the generator. By using the simulation data of 45 variations of the consumer load sample, the result is that there are only 4 samples where the load controller is not working well. For the 4 samples, the generator was loaded beyond its full load tolerance limit (full load tolerance of $5 \mathrm{~kW} \pm 5 \%$ ). Overall, based on the simulation results, it can be said that the generator load controllers tested in this study have good performance.
\end{abstract}

Keywords: 5 kW micro-hydro, Electronic load controller, Dimmer circuit, Step motor

\section{Introduction}

To control the system frequency generated by the micro-hydro generator so that it always remains at a frequency of $50 \mathrm{~Hz}$ despite load fluctuations, a controller is needed. In a micro hydropower plant that uses synchronous generator as a generator, an electronic load controller (ELC) is generally used. Meanwhile, in a micro hydropower plant with an asynchronous generator as generator, the induction generator controller (IGC) is used. Voltage and frequency settings in micro-hydro systems are much easier to achieve using electronic load controllers. Because the device responds quickly in case of fluctuations in consumer loads. Besides that, the average cost for making an electronic load control unit is $10 \%$ compared to using a mechanical governor. Generally, electronic load controllers are always equipped with ballast loads or dump loads. Ballast load functions to balance the electrical energy generated by the generator and the load. If the load from the customer is smaller than the generator's electrical energy production, the rest will be transferred to the ballast load.

The utilization of micro-hydro in Indonesia, especially low-power micro-hydro, has been utilized by the community in Bulukumba Regency, South Sulawesi Province. A $5 \mathrm{~kW}$ generator has been operated in Katimbang Village, Borong Rappoa District, Kindang Regency, Bulukumba Regency, South Sulawesi Province to distribute electrical energy to 15 households. The micro hydropower plants that are operated in this area all use an isolated system (off-grid), where each generator supplies its load. For load control, the generator uses an electronic load control system with a ballast load.

Methods and power electronic configurations used in electronic load controllers for microhydropower plants from 1980 until now are described in detail in [1-3]. In the future, the use of lowpower micro hydro and pico hydro power plants is also in great demand, especially for rural areas. Technologies related to low-power micro hydro and pico hydropower plants are described in [4-6]. This research proposes a new electronic load control scheme for a simple and inexpensive $5 \mathrm{~kW}$ micro-hydro power plant, namely a dimmer and stepper motor-based generator load controller. With the consideration that the main components that make up this controller are not expensive. The dimmer circuit module (also known as the ac regulator) is easy to find, and is available with a capacity of $1,000 \mathrm{~W} ; 5,000 \mathrm{~W}$ to 10,000 
W. The generator load control results of this study are projected to be applied to a low-power Microhydro Power Plant (MHPP).

\section{Materials and methods}

For simulation purposes in this study, 2 computer programs were created, namely the generator loading program and the control program. The generator consumer load data is made to vary from no load to full load. Data communication between a computer with a PPI $8255 \mathrm{C}$ device and a stepper motor using a USB serial cable to DB 9. Materials used include USB to DB9 serial cable (BF-810F), PPI 8255 $\mathrm{C}$ kit, stepper motor 28BYJ-48 (working voltage: 5V DC, number of phases: 4, step angle: $5.625^{\circ} / 64$, coil: Unipolar 5 coils), motor driver, rotating arm, and ballast load.

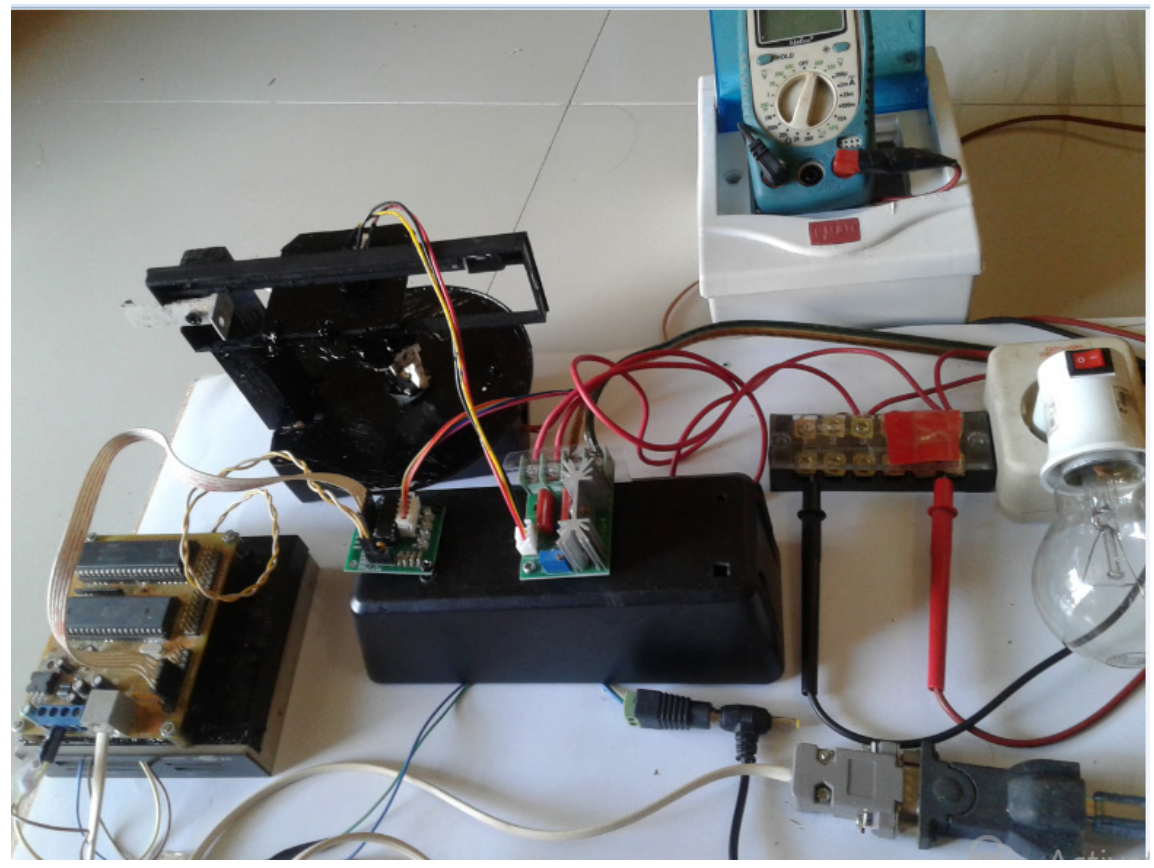

Figure 1 The device used in a simulation.

\section{Schematic diagram}

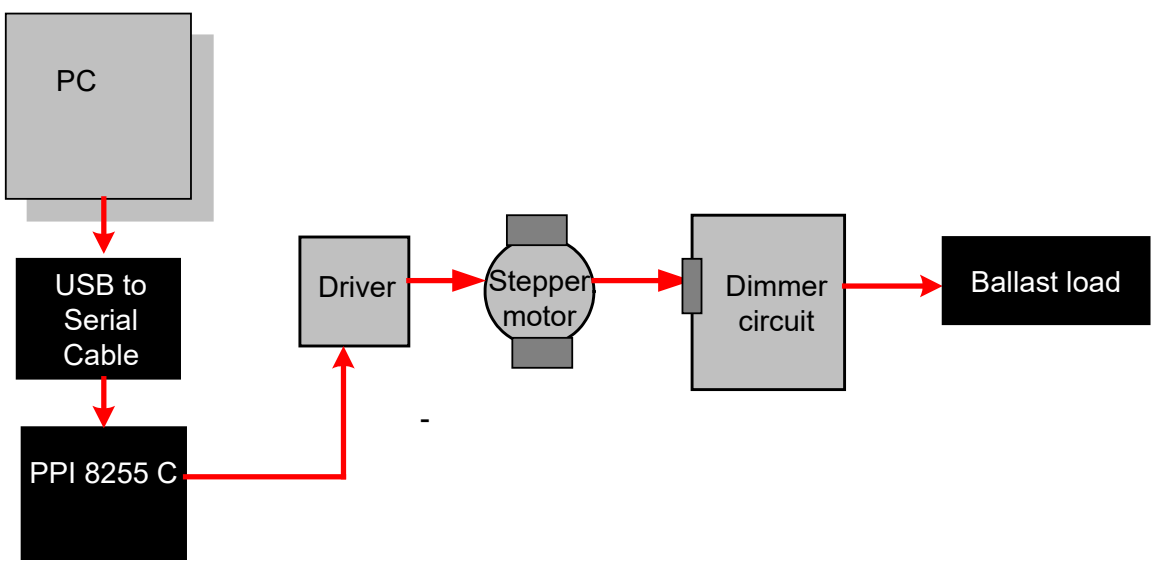

Figure 2 Schematic diagram of the device used in the simulation. 


\section{Dimmer circuit}

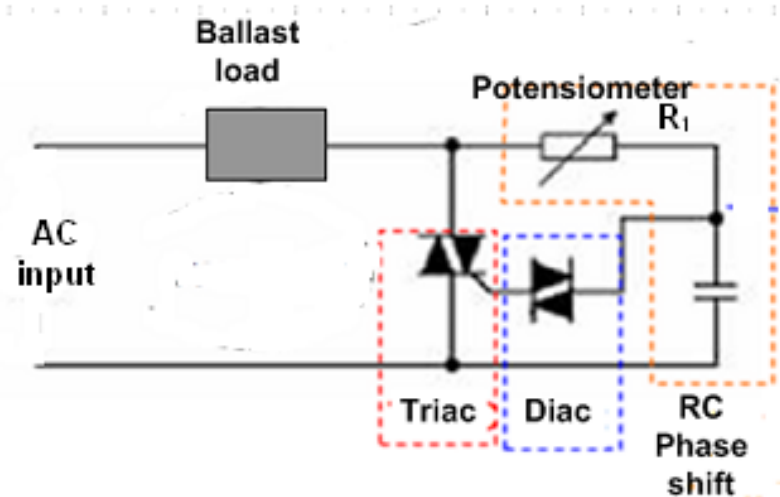

Figure 3 Dimmer circuit with RC phase shift.

In Figure 3, to change the power in the ballast load, first, RC phase shift is used to delay the trigger voltage on the Triac component. The symmetrical characteristics of the Diac components are used to trigger the Triac symmetrically. The Triac trigger angle can be changed by varying the resistance value of the potentiometer R1. Because the dimmer circuit in Figure 3 is loaded with a resistive ballast load, the electric power absorbed by the load can be adjusted by varying the value of $\mathrm{R} 1$.

\section{Step motor}

A stepper motor is a DC motor that moves not continuously but moves in discrete steps. The most commonly used step motor is the 28-BYJ48 step motor. Used on DVD drives, motion cameras, and many more places. The motor has a unipolar 4 coil arrangement and each coil is rated $+5 \mathrm{~V}$ so it is relatively easy to control with a basic microcontroller. These motors have a step angle of $5.625 \%$, this means that the motor has to make 64 steps to complete 1 revolution and for each step will cover $5.625^{\circ}$ then the level of control is also high.

Table 1 Rotation of the stepper motor clockwise.

\begin{tabular}{ccccccccc}
\hline \multirow{2}{*}{ Motor coil } & \multicolumn{7}{c}{ The pulse sequence is given to rotating the motor clockwise } \\
\hline coil 1 & 0 & 0 & 1 & 1 & 1 & 1 & 1 & 0 \\
coil 3 & 1 & 0 & 0 & 0 & 1 & 1 & 1 & 1 \\
coil 2 & 1 & 1 & 1 & 0 & 0 & 0 & 1 & 1 \\
coil 4 & 1 & 1 & 1 & 1 & 1 & 0 & 0 & 0 \\
$+5 \mathrm{~V}$ source & 1 & 1 & 1 & 1 & 1 & 1 & 1 & 1 \\
\hline
\end{tabular}

To rotate the motor in the opposite direction, counterclockwise, the motor coil is given a pulse in the opposite order in Table 1. For example, for step 1 clockwise, the coil [ [ $\left.\begin{array}{llll}1 & 3 & 2 & 4\end{array}\right]$ is given a pulse $\left[\begin{array}{lllll}0 & 1 & 1 & 1\end{array}\right]$. For counterclockwise rotation, the coil $\left[\begin{array}{llll}1 & 3 & 2 & 4\end{array}\right]$ is given the reverse pulse, namely $\left[\begin{array}{llll}1 & 1 & 1 & 0\end{array}\right]$.

\section{Coil 2}

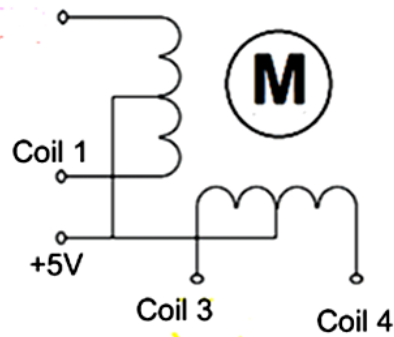

Figure 5 28-BYJ48 step motor coil. 


\section{Flow chart}

The first step taken to simulate a step-motor-based generator load controller and the dimmer circuit is to measure the triac trigger angle for each step of the stepper motor. After the triac per-step trigger angle data is obtained, the data is then used to adjust the work of the stepper motor so that the ballast load gets power according to the consumer load. The flow chart of a generator load controller simulation using a stepper motor and a dimmer circuit is shown in Figure 6.

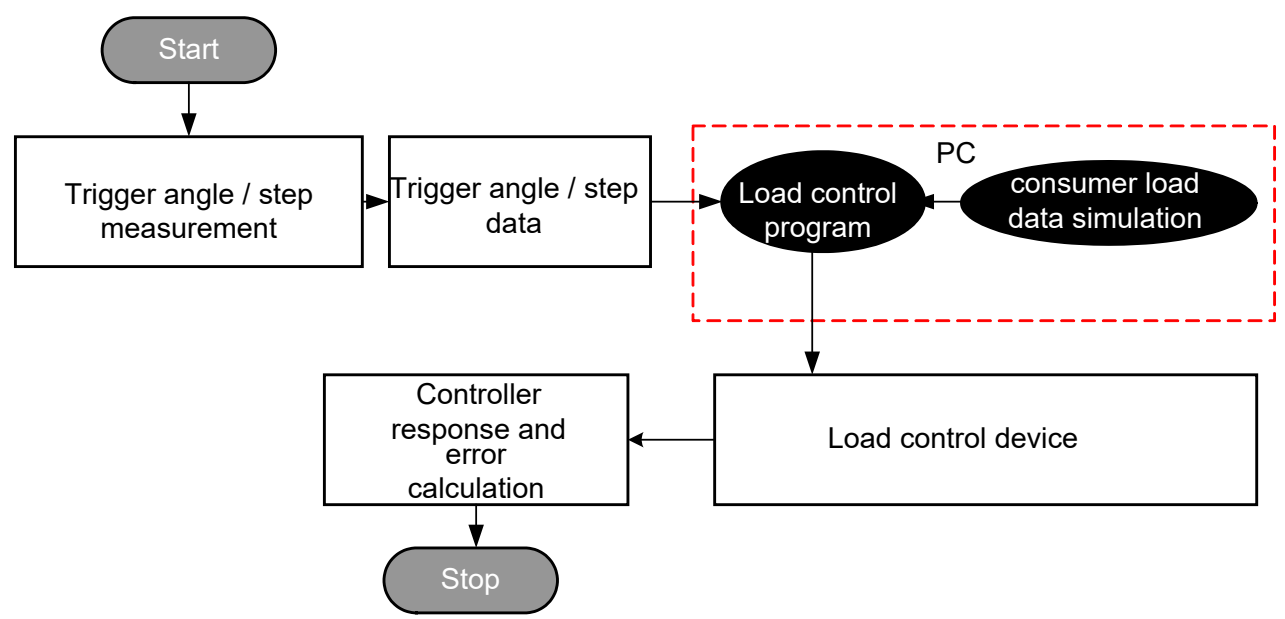

Figure 6 Flow chart of a generator load controller simulation using a stepper motor and a dimmer circuit.

\section{Triac trigger angle measurement}

The triac output voltage is formulated by the equation;

$V_{0(R M S)}=V_{s} f_{\alpha}$

where $\mathrm{V}_{\mathrm{s}}$ is the effective value of the supply voltage and $f_{\alpha}$

$f_{\alpha}=\sqrt{\frac{1}{\pi}\left[(\pi-\alpha)+\frac{\sin 2 \alpha}{2}\right]}$

If the source voltage and the triac output voltage are known from the voltmeter measurement results, then the triac trigger angle can be found by Eq. (1). In this study, this method was used to determine the triac trigger angle using a digital voltmeter, and the results are given in Table 2.

Table 2 The measurement results of the triac trigger angle.

\begin{tabular}{cccccc}
\hline $\begin{array}{c}\text { Step } \\
\text { (Stepper } \\
\text { motor) }\end{array}$ & $\begin{array}{c}\text { Triac trigger } \\
\text { angle }\left(^{\circ}\right)\end{array}$ & $\begin{array}{c}\text { Step } \\
\text { (Stepper } \\
\text { motor) }\end{array}$ & $\begin{array}{c}\text { Triac trigger } \\
\text { angle }\left(^{\circ}\right)\end{array}$ & $\begin{array}{c}\text { Step } \\
\text { (Stepper motor) }\end{array}$ & $\begin{array}{c}\text { Triac trigger } \\
\text { angle }\left(^{\circ}\right)\end{array}$ \\
\hline 1 & 20 & 17 & 88 & 33 & 128 \\
2 & 33 & 18 & 92 & 34 & 129 \\
3 & 40 & 19 & 95 & 35 & 131 \\
4 & 45 & 20 & 97 & 36 & 132 \\
5 & 52 & 21 & 100 & 37 & 134 \\
6 & 55 & 22 & 103 & 38 & 135 \\
7 & 62 & 23 & 105 & 39 & 138 \\
8 & 66 & 24 & 106 & 40 & 139 \\
9 & 70 & 25 & 109 & 41 & 140 \\
10 & 75 & 26 & 112 & 42 & 142 \\
11 & 78 & 27 & 115 & 43 & 143 \\
12 & 83 & 28 & 116 & 44 & \\
\hline
\end{tabular}




\begin{tabular}{cccccc}
\hline $\begin{array}{c}\text { Step } \\
\text { (Stepper } \\
\text { motor) }\end{array}$ & $\begin{array}{c}\text { Triac trigger } \\
\text { angle }\left(^{\circ}\right)\end{array}$ & $\begin{array}{c}\text { Step } \\
\text { (Stepper } \\
\text { motor) }\end{array}$ & $\begin{array}{c}\text { Triac trigger } \\
\text { angle }\left(^{\circ}\right)\end{array}$ & $\begin{array}{c}\text { Step } \\
\text { (Stepper motor) }\end{array}$ & $\begin{array}{c}\text { Triac trigger } \\
\text { angle }\left(^{\circ}\right)\end{array}$ \\
\hline 13 & 77 & 29 & 118 & 45 & 144 \\
14 & 79 & 30 & 120 & 46 & 146 \\
15 & 82 & 31 & 130 & 47 & 147 \\
16 & 85 & 32 & 127 & 48 & 148 \\
\hline
\end{tabular}

For example, if the motor is run with several steps of 16 , and the measured source voltage on the voltmeter $\mathrm{V}_{\mathrm{s}}=220 \mathrm{Volt}$, and the voltage at the balancing load $\mathrm{V}_{0}=164$ Volts, then based on the calculation, the triac trigger angle is $85^{\circ}$

Table 3 Measurement of the triac trigger angle for $\mathrm{V}_{\mathrm{s}}=220$ Volts.

\begin{tabular}{cccc}
\hline $\begin{array}{c}\text { Voltage } \\
\begin{array}{c}\text { Calculate the ballast } \\
\text { load (Volt) }\end{array}\end{array}$ & Triac trigger angle $\left(^{\circ}\right)$ & $\begin{array}{c}\text { The measured voltage } \\
\text { on the ballast load } \\
\text { (Volt) }\end{array}$ & $\begin{array}{c}\text { Step } \\
\text { (Stepper motor) }\end{array}$ \\
\hline 165.57 & 84 & & \\
163.96 & 85 & 164 & 16 \\
162.32 & 86 & & \\
\hline
\end{tabular}

Generator load simulation data (5,000 Watt full load)

Table 4 Generator load simulation data.

\begin{tabular}{ccccc}
\hline No. & $\begin{array}{c}\text { Generator Load Simulation Data } \\
\text { Power to Consumer } \\
\text { Load }\end{array}$ & $\begin{array}{c}\text { Power on ballast } \\
\text { load, calculation } \\
\text { result }\end{array}$ & $\begin{array}{c}\text { Power on ballast load } \\
\text { distributed by the controller, } \\
\text { measurement results }\end{array}$ & Error \\
\cline { 2 - 3 } & $\mathbf{P}_{\mathbf{K}}$ (Watt) & $\mathbf{P}_{\mathbf{D}}$ (Watt) & $\mathbf{P}_{\mathbf{R}}$ (Watt) & e (Watt) \\
\hline 1 & 2654 & 2346 & 2223 & 123 \\
2 & 3896 & 1104 & 978 & 126 \\
3 & 4670 & 330 & 263 & 67 \\
4 & 650 & 4350 & 4546 & 196 \\
5 & 2844 & 2156 & 1950 & 206 \\
6 & 2347 & 2653 & 2611 & 42 \\
7 & 60 & 4940 & 4956 & 16 \\
8 & 1686 & 3314 & 3157 & 157 \\
9 & 811 & 4189 & 4220 & 51 \\
10 & 3971 & 329 & 978 & 129 \\
11 & 1556 & 2357 & 3315 & 48 \\
12 & 2643 & 4172 & 2223 & 40 \\
13 & 828 & 1990 & 4220 & 118 \\
14 & 3010 & 3685 & 1950 & 96 \\
15 & 1315 & 1730 & 3567 & 218 \\
16 & 3270 & 1554 & 1634 & 108 \\
17 & 3446 & 1259 & 1336 & 136 \\
18 & 3741 & 2747 & 1151 & 97 \\
19 & 2253 & 4581 & 2611 & 106 \\
20 & 419 & 3855 & 4810 & 308 \\
21 & 1145 & 433 & 3758 & 107 \\
22 & 4567 & 4238 & 327 & \\
23 & 762 & 871 & 4546 & \\
24 & 4129 & & 978 & \\
\hline
\end{tabular}




\begin{tabular}{|c|c|c|c|c|}
\hline \multirow{3}{*}{ No. } & \multicolumn{2}{|c|}{ Generator Load Simulation Data } & \multirow{2}{*}{$\begin{array}{l}\text { Power on ballast load } \\
\text { distributed by the controller, } \\
\text { measurement results }\end{array}$} & \multirow[b]{2}{*}{ Error } \\
\hline & $\begin{array}{l}\text { Power to Consumer } \\
\text { Load }\end{array}$ & $\begin{array}{l}\text { Power on ballast } \\
\text { load, calculation } \\
\text { result }\end{array}$ & & \\
\hline & $\mathbf{P}_{K}$ (Watt) & $\mathbf{P}_{\mathrm{D}}$ (Watt) & $P_{R}$ (Watt) & e (Watt) \\
\hline 25 & 2692 & 2308 & 2113 & 195 \\
\hline 26 & 4981 & 19 & 174 & 155 \\
\hline 27 & 391 & 4609 & 4673 & 64 \\
\hline 28 & 2213 & 2787 & 2611 & 176 \\
\hline 29 & 533 & 4467 & 4546 & 79 \\
\hline 30 & 4809 & 191 & 174 & 17 \\
\hline 31 & 23 & 4977 & 4956 & 21 \\
\hline 32 & 3875 & 1125 & 978 & 147 \\
\hline 33 & 4087 & 913 & 978 & 65 \\
\hline 34 & 4343 & 657 & 427 & 230 \\
\hline 35 & 422 & 4578 & 4673 & 95 \\
\hline 36 & 1999 & 3001 & 2611 & 390 \\
\hline 37 & 1299 & 3701 & 3567 & 134 \\
\hline 38 & 4000 & 1000 & 978 & 22 \\
\hline 39 & 2157 & 2843 & 2389 & 454 \\
\hline 40 & 4553 & 447 & 327 & 120 \\
\hline 41 & 909 & 4091 & 3938 & 153 \\
\hline 42 & 1319 & 3681 & 3567 & 114 \\
\hline 43 & 728 & 4272 & 4546 & 274 \\
\hline 44 & 4346 & 654 & 427 & 227 \\
\hline 45 & 2899 & 2101 & 1950 & 151 \\
\hline
\end{tabular}

The data in Table 4 column 4 is the power at the ballast load obtained from the measurement results $\left(\mathrm{P}_{\mathrm{R}}\right) . \mathrm{P}_{\mathrm{R}}$ power calculation using Eq. (3);

$P_{R}=\frac{V_{0}^{2}}{R_{\text {ballast }}}$

where $\mathrm{V}_{0}$ is the voltage measured at the ballast load, and $\mathrm{R}_{\text {ballast }}$ is the ballast load resistance value, $R_{\text {ballast }}$ $=9.68 \Omega$. For example, for load no. 1 , the measured voltage on the ballast load by the digital voltmeter is 147 volts. Therefore, the power on the ballast load that is realized by the controller is;

$P_{R}=\frac{V_{0}^{2}}{R_{\text {ballast }}}=\frac{147^{2}}{9,68}=2,223$ Watt

The data in Table 4 column 5 is the difference between the power in the ballast load based on measurement (PR) and the power on the ballast load based on calculations (PD). Calculated using Eq. (4);

$e=\left|\left(P_{D}-P_{R}\right)\right|$

\section{Results and discussion}

To determine the performance of a dimmer circuit-based load controller with a potentiometer position control, a simulation is carried out, namely, the generator is given a consumer load $\left(\mathrm{P}_{\mathrm{K}}\right)$ as listed in table 4 column 2. Simulation data of consumer loads on the generator, as well as programs for load control, are made with the Matlab software. Then the output of the control program written with the Matlab instruction will be forwarded to the PPI 8255 to place the potentiometer in a certain position, and this means that the triac trigger angle on a certain dimmer circuit is also the amount. The position of the potentiometer is regulated by the program and its movement is carried out by the rotating arm, where the shaft of the rotating arm is united with the shaft of the stepper motor. Furthermore, the work of the controller is observed to determine whether the controller is working properly or not. If the controller is working properly, the load controller instructs the stepper motor to move the potentiometer at a certain 
position so that a certain triac trigger angle is obtained which impacts the power distribution to the ballast load which is the same or close to the power value that should be supplied to the ballast load (see Table 4 column 3). In Table 4, the value of power that should be supplied to the ballast load is referred to as the calculated ballast load power.

\section{Program}

The program for the movement of the potentiometer position by a stepper motor based on the amount of consumer power using the Matlab code is shown in the following section;

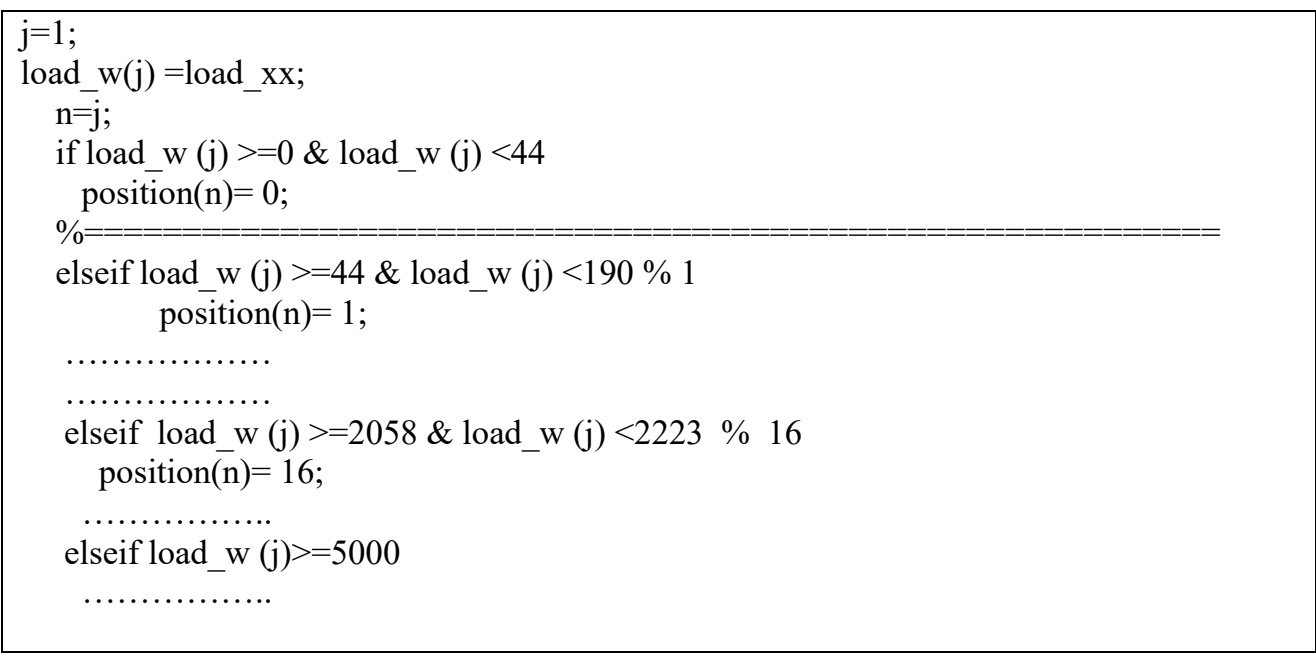

In the above program, for example if the $\mathrm{P}_{\mathrm{K}}$, consumer load is greater or equal to 2058 Watts and smaller than 2233 Watts, the stepper motor will place the potentiometer position at position 16. Code Matlab
elseif load_w (j) $>=2058 \&$ load_w (j) $<2223 \% 16$ $\operatorname{position}(\mathrm{n})=16$;

where position (n) is the m-file function.

Program to adjust the movement of the stepper motor from 1 position to another or tracking the motor moving clockwise or counterclockwise using the Matlab software. In this case, the Matlab communication with the PPI $8255 \mathrm{C}$ device, and to the stepper motor driver uses the Com Serial Port 3, as in the following example; 

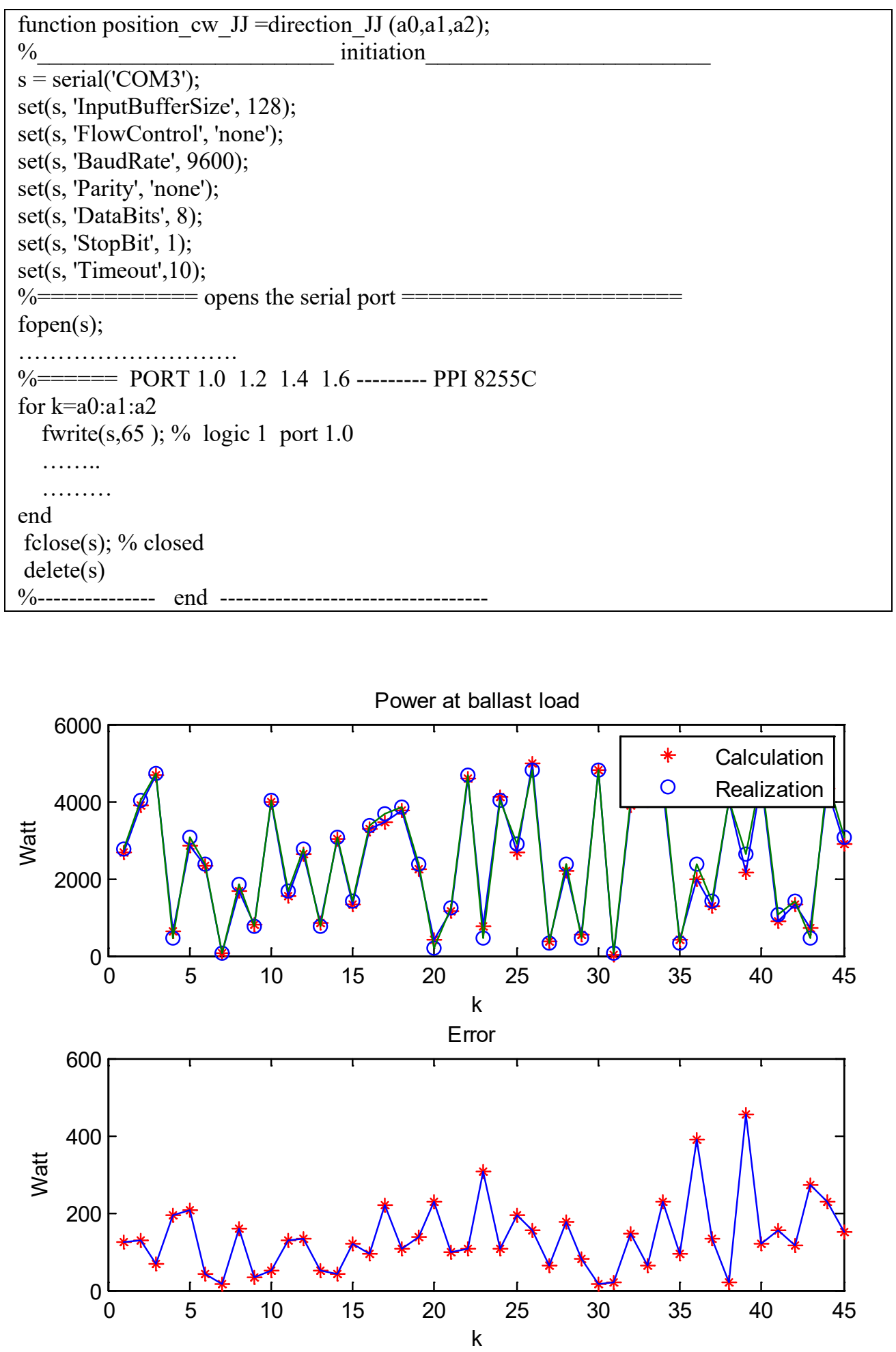

Figure 7 Power distributed controller to ballast load and error. 

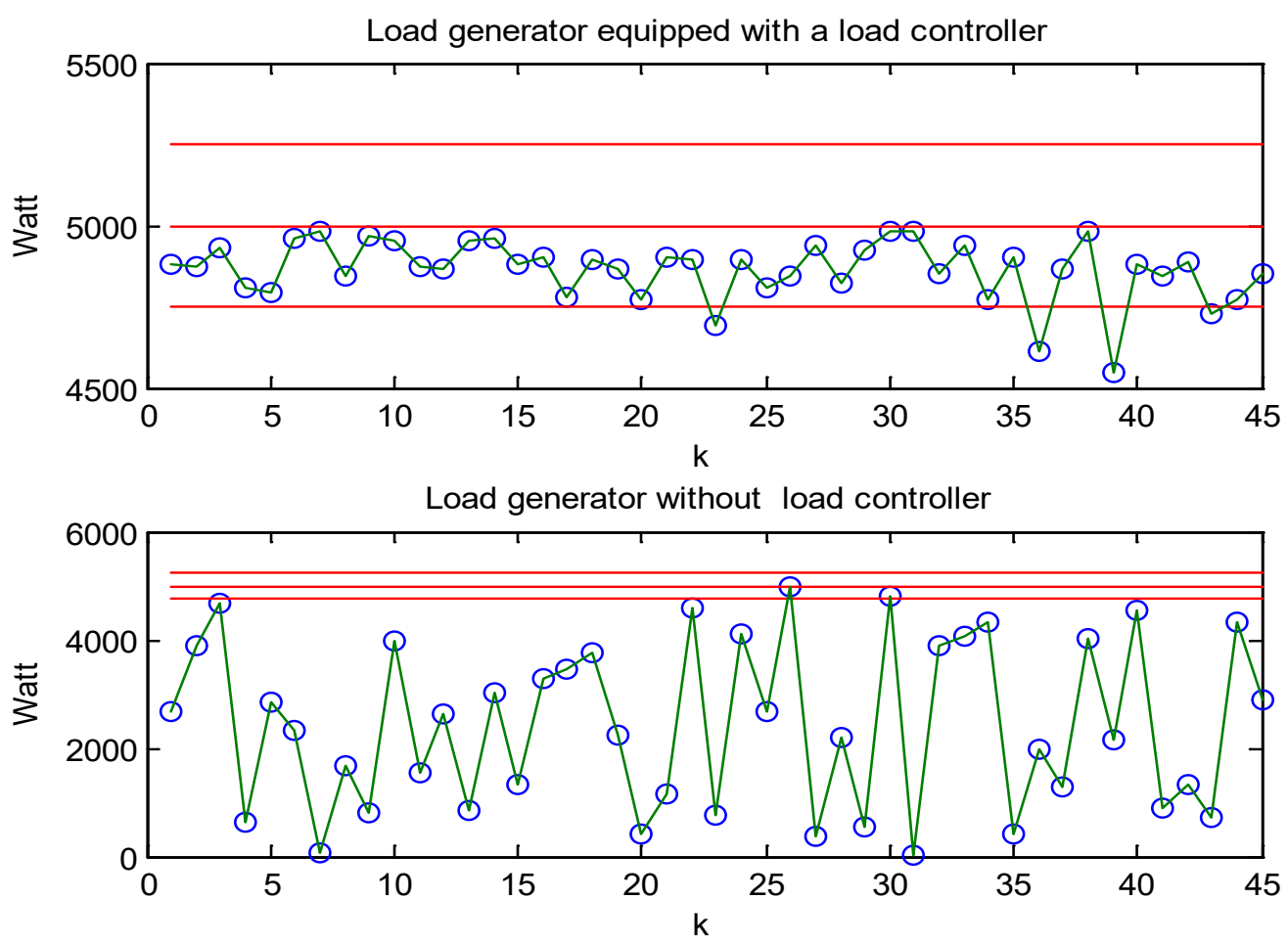

Figure 8 Generator load controller simulation results for various consumer loads.

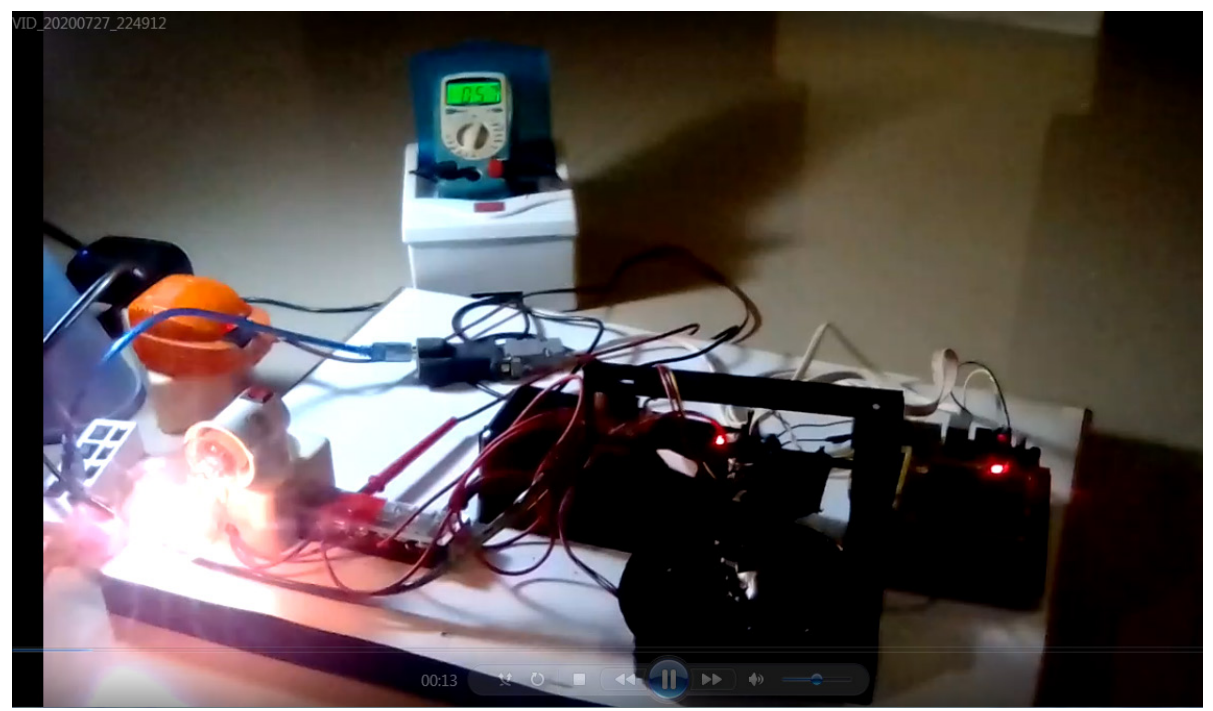

Figure 9 Run the new schematic generator load controller simulation.

Figure 8 shows the performance of a generator load controller with a stepper motor position control in regulating the generator load so that the generator remains at full load despite fluctuations in consumer loads. If the generator is fully loaded (in this case 5,000 Watts) then the system frequency is maintained at a frequency of $50 \mathrm{~Hz}$, and the nominal voltage of the system is 220 Volts. If tolerance of $\pm 5 \%$ of the full load of the generator is used, then based on Figure 8 the load controller is still working quite well. The 45 samples of different consumer loads, there are only 4 samples where the controller work is not good which results in the generator being burdened beyond its full load tolerance limit. These loads are listed in Table 5, namely load 23 with an error of $308 \mathrm{~W}$, load 36 with an error of $390 \mathrm{~W}$, load 39 with an error of $456 \mathrm{~W}$, and load 43 with an error of $274 \mathrm{~W}$.

Table 5 Power in ballast loads for consumer loads no. 23, 36, 39, and 43. 


\begin{tabular}{|c|c|c|c|c|}
\hline \multirow{3}{*}{ No. } & \multicolumn{2}{|c|}{ Generator load simulation data } & \multirow{2}{*}{$\begin{array}{l}\text { Power on ballast load } \\
\text { distributed by the } \\
\text { controller, } \\
\text { measurement results }\end{array}$} & \multirow[b]{2}{*}{ Error } \\
\hline & $\begin{array}{c}\text { Power to consumer } \\
\text { load }\end{array}$ & $\begin{array}{c}\text { Power on ballast } \\
\text { load, calculation } \\
\text { result }\end{array}$ & & \\
\hline & $P_{K}$ (Watt) & $P_{R}$ (Watt) & $P_{R}$ (Watt) & e (Watt) \\
\hline 23 & 762 & 4238 & 4546 & 308 \\
\hline 36 & 1999 & 3001 & 2611 & 390 \\
\hline 39 & 2157 & 2843 & 2389 & 454 \\
\hline 43 & 728 & 4272 & 4546 & 274 \\
\hline
\end{tabular}

The explanation of why the controller works poorly for the case of consumer generator loads in Table 5, the problem lies in the degree/step value of the stepper motor 28BYJ-48 which is too large. One step stepper motor of this type produces $5.625^{\circ}$ rotation. If a stepper motor with a smaller degree/step is used, for example, $1.8 \%$ step, the controller will work even better. Figure 8 shows the characteristics of the load controller in maintaining the generator load so that the generator load remains around its full load even though the consumer load changes.

\section{Conclusions}

The electronic load controller for a $5 \mathrm{kWatt}$ micro-hydro power plant made in this study is built from a dimmer circuit and a stepper motor with a control program using Matlab software, and the PPI 8255 interface device. Using a dimmer circuit built from diac, triac, a variable resistor (pot), and capacitors. As well as using a 28BYJ-48 stepper motor.

Simulation is made to determine the performance of load controllers in controlling the distribution of power to the ballast load when the generator supplies power to consumers less than the full load of the generator. By using the simulation data 45 variations of the consumer load sample, the result is that there are only 4 samples where the load controller is not working well. For the 4 samples, the generator was loaded beyond its full load tolerance limit (full load tolerance of $5 \mathrm{~kW} \pm 5 \%$ ). Each of these loads is a consumer load of 762, 1999, 2157 and $728 \mathrm{~W}$. For the 4 cases the controller works poorly because the degree/step value of the 28BYJ-48 stepper motor is too large, which is 1 step stepper motor. 28BYJ-48 provides $5.625^{\circ}$ rotation. If the 28BYJ-48 stepper motor is replaced with a stepper motor that has a smaller rotation value per step, for example, $1.80 \%$ step, the controller will work even better.

Overall, based on the simulation results, it can be said that the performance of the generator load controllers made in this study has a fairly good performance.

\section{Acknowledgements}

Thank you to the Institute for Development and Community Service Research, the University of Muhammadiyah Makassar, which has provided internal research grants for 2020 with No. Contract: 0011/ KONT-PENL/PENGABD/IV/1441/2020.

\section{References}

[1] RR Singha, BA Kumar, D Shruthi, R Pandad and CT Raj. Review and experimental illustrations of electronic load controller used in standalone micro-hydro generating plants. Eng. Sci. Tech. 2018; 21, 886-900.

[2] NW Aung and AZ Ya. Microcontroller based electrical parameter monitoring System of electronic load controller used in micro hydro power plant. J. Electr. Electron. Eng. 2015; 3, 97 109.

[3] P Kapoor, L Phunchok and S Kumar. Frequency control of micro hydro power plant using electronic load controller. J. Eng. Res. Appl. 2012; 2, 733-7.

[4] AMA Haidar, MFM Senan, A Noman and T Radman. Utilization of pico hydro generation in domestic and commercial loads. Renew. Sustain. Energ. Rev. 2012; 16, 518-24.

[5] KH Motwani, SV Jain and RN Patel. Cost analysis of pump as turbine for pico hydropower plants - a case study. Proc. Eng. 2013; 51, 721-6.

[6] AA Lahimer, MA Alghoul, K Sopian, N Amin, N Asim and MI Fadhel. Research and development aspects of pico-hydro power. Renew. Sustain. Energ. Rev. 2012; 16, 5861-78 
[7] EB Shandarova and SA Shwab. Voltage quality of micro-hydroelectric station with rectifier ballast load. In: Proceedings of the International Conference on Mechanical Engineering, Automation and Control Systems, Tomsk, Russia. 2014.

[8] U ur Rehman and M Riaz. Design and implementation of electronic load controller for small hydro power plants. In: Proceedings of the International Conference on Computing, Mathematics and Engineering Technologies, Sukkur, Pakistan. 2018.

[9] S Singh, ML Azad and A Kumar. Electronic load controllers for self-excited induction generator. In: Proceedings of the International Conference on Innovation and Challenges in Cyber Security, Greater Noida, India. 2016.

[10] G Nel and W Doorsamy. Development of an intelligent electronic load controller for standalone micro-hydropower systems. In: Proceedings of the 2018 IEEE PES/IAS PowerAfrica, Cape Town, South Africa. 2018.

[11] ÉS Melo, PC Rosa and ÊR Ribeiro. Electronic load controller of a micro-hydro generator for standalone operation. In: Proceedings of the 2013 Brazilian Power Electronics Conference, Gramado, Brazil, 2013.

[12] SK Rai, OP Rahi and S Kumar. Implementation of electronic load controller for control of micro hydro power plant. In: Proceedings of the 2015 International Conference on Energy Economics and Environment, Greater Noida, India. 2015

[13] J Smith, J Speakes and MH Rashid. An overview of the modern light dimmer: Design operation, and application. In: Proceedings of the $37^{\text {th }}$ Annual North American Power Symposium, Ames, IA, USA. 2005.

[14] A Kumar and RP Gupta. Speed and position control of stepper motor using 8051 microcontroller. Int. J. Sci. Res. Dev. 2015; 3, 267-71.

[15] SV Kamble and SM Akolkar. Load frequency control of micro hydro power plant using fuzzy logic controller. In: Proceedings of the 2017 IEEE International Conference on Power, Control, Signals and Instrumentation Engineering, Chennai, India. 2017.

[16] R Harisudhan, MG Kumar, AU Prakash and P Sathya. Stepper motor control using arduino atmega 328 microcontroller. Int. J. Sci. Res. Dev. 2015; 2, 778-80.

[17] I Virgala, M Kelemen, A Gmiterko and T Lipták. Control of stepper motor by microcontroller. $J$. Autom. Contr. 2015; 3, 131-4.

[18] MH Riaz, MK Yousaf; T Izhar; T Kamal, M Danish, A Razzaq and MH Qasmi. Micro hydro power plant dummy load controller. In: Proceedings of the $1^{\text {st }}$ International Conference on Power, Energy and Smart Grid, Mirpur Azad Kashmir, Pakistan. 2018.

[19] SK Rai, OP Rahi and S Kumar. Implementation of electronic load controller for control of micro hydro power plant. In: Proceedings of the 2015 International Conference on Energy Economics and Environment, Greater Noida, India. 2015.

[20] A Hafid and R Rahmania. Analisis pengendali beban elektronik untuk pembangkit listrik tenaga pikohidro denganh metode kendali sudut fase dan beban biner. Jurnal Informatika Sains dan Teknologi 2018; 3, 31-40. 